DOI: $10.2478 /$ lpts-2020-0004

\title{
STUDY OF FEED HORN SOLUTIONS FOR IRBENE RT-32 RADIO TELESCOPE
}

\author{
M. Bleiders
}

\author{
Engineering Research Institute \\ "Ventspils International Radio Astronomy Center", \\ Ventspils University of Applied Sciences, \\ 101 Inzenieru Str., Ventspils, LV-3601, LATVIA \\ E-mail: marcis.bleiders@venta.lv
}

\begin{abstract}
Various feasible solutions of Irbene RT-32 secondary focus feed antennas are designed and compared in the present study. The examined feed antennas include smooth wall and corrugated horns with linear and shaped profiles. Mode matching technique is employed for simulation of scattering parameters and radiation patterns. Genetic algorithm is used for optimisation of horn profile for the best cross-polarization, and aperture efficiency performance. Although the presented horns are valid for any frequency band, different solutions allow choosing the best combination of factors, such as electrical parameters, bandwidth, physical size and complexity of manufacturing.
\end{abstract} telescope

Keywords: antenna optimisation, feed horn, Irbene RT-32 radio

\section{INTRODUCTION}

Planning has been recently started to expand frequency range of Irbene RT-32 radio telescope by installing new receivers in addition to existing $\mathrm{C}-\mathrm{X}$ band system. The key component of any reflector antenna receiver system is feed horn, which must be optimised for geometry of specific reflector and it directly affects important performance parameters of the whole radio telescope, such as aperture efficiency, cross-polarization and bandwidth. Although already available $\mathrm{C}-\mathrm{X}$ band corrugated horn design could be scaled for operation at different frequency bands, in reality it is not always practical. For example, in case of RT-32 geometry, the required feed horn at $\mathrm{L}$ and/or $\mathrm{S}$ band is physically very large and corrugated design would be expensive and heavy, so smooth wall horn design would be preferred. Even though the existing horn design has almost octave bandwidth with good cross-polarization levels, using careful profile optimisation it is possible to obtain corrugated horn with even better performance, such as the improved aperture efficiency bandwidth. The present paper summarises the initial design of four feasible feed horn options, which include a 
smooth wall and corrugated designs with various profile shapes. The whole design process is briefly described, starting from the required performance parameters and ending with discussion about the obtained performance.

\section{DESIGN PROCEDURE}

Required performance of RT-32 secondary focus feed horn is summarised in Table 1. The main requirement that is set by geometry of RT-32 is a secondary mirror subtended angle and the remaining parameters are either derived from a subtended angle or are rule of thumb values such as amplitude taper at a mirror edge and phase error. The main electrical performance parameters are the maximum cross-polarization level and total illumination efficiency, which must be as good as possible but practically feasible values of better that $20 \mathrm{~dB}$ and $60 \%$ respectively are defined.

Table 1

Required Performance of RT-32 Secondary Focus Feed Antenna

\begin{tabular}{|l|c|}
\hline Secondary mirror subtended angle & 21 \\
\hline Equivalent f/D ratio & 2.7 \\
\hline Amplitude edge taper & $13 \mathrm{~dB}$ \\
\hline Feed aperture phase error & $\approx 1.3 \mathrm{rad}(0.1 \ldots 0.3)$ \\
\hline Main lobe full beam-width & $25 \mathrm{dBi}$ \\
\hline Directivity & $<-20 \mathrm{~dB}(>0.99)$ \\
\hline Maximum cross-polarization level & $<-25 \mathrm{~dB}$ \\
\hline Sidelobe level \& co-polar beam & $>60 \%$ \\
\hline Input return loss & $<-25 \mathrm{~dB}$, with equal E/H plane patterns \\
\hline Illumination efficiency & Low cost, compact size, small weight \\
\hline Fractional bandwidth & $<50$ (octave is 67 ) \\
\hline Other & Lom \\
\hline
\end{tabular}

Using the shown requirements of subtended angle, amplitude edge taper and phase error, initial dimensions of conical profile feed horn are estimated using the Gaussian beam technique [1]. The required aperture diameter and slant length to maximise coupling to the fundamental Gaussian beam mode are $a_{a p p} \approx 3.3 \lambda$ and $L \approx 22 \lambda$, respectively. Radius of input waveguide $a_{\text {in }}$ is set to $0.48 \lambda$ that is approximately in the middle between TE11 and TM11 mode cut-off wavelengths. The initial profile shape is then parametrized and optimised using a classical genetic algorithm combined with an efficient mode matching technique [2],[3], which was implemented using MATLAB and verified against CST MWO. Overall block diagram of the design algorithm is shown in Fig. 1.

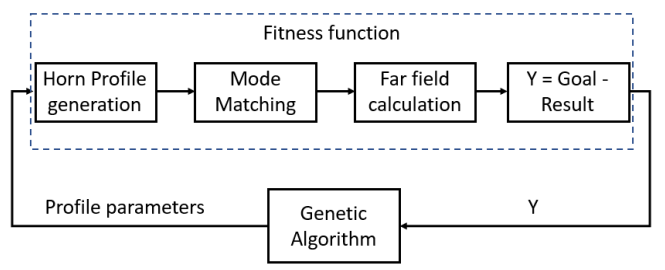

Fig. 1. Block diagram of the employed horn profile optimisation algorithm. 
Average of maximum cross-polarization at various frequencies has been used as an optimisation goal in this study, and the goal for the best total illumination efficiency of secondary mirror has been tested with similar results.

\section{RESULTS AND DISCUSSION}

Resulting profiles of four feasible horns are shown in Fig. 2. Horn \#1 is classical Potter dual mode horn with optimised double-step waveguide step structure at input to generate TM11 mode with the correct amount and phase at aperture [4]. Horn \#2 is a smooth wall multimode horn with three discrete sections with optimisation carried out on section length and radii of the nodes. Horn \#3 is a corrugated horn with a linear conical profile designed according to [5], with additional optimisation carried out on input section, which has gradual change in groove width to improve the bandwidth of return loss [6]. Horn \#4 is also a corrugated horn with a similar multiple discrete section profile as \#2 but with total length decrease of $30 \%$. All horns have the same aperture radius of 3.3 $\lambda$. Typically for genetic algorithm optimisation result to converge, 500-1000 evaluations of fitness function are needed in case of horns \#2 and \#4, but much less in case of linear profiles \#1 and \#3.
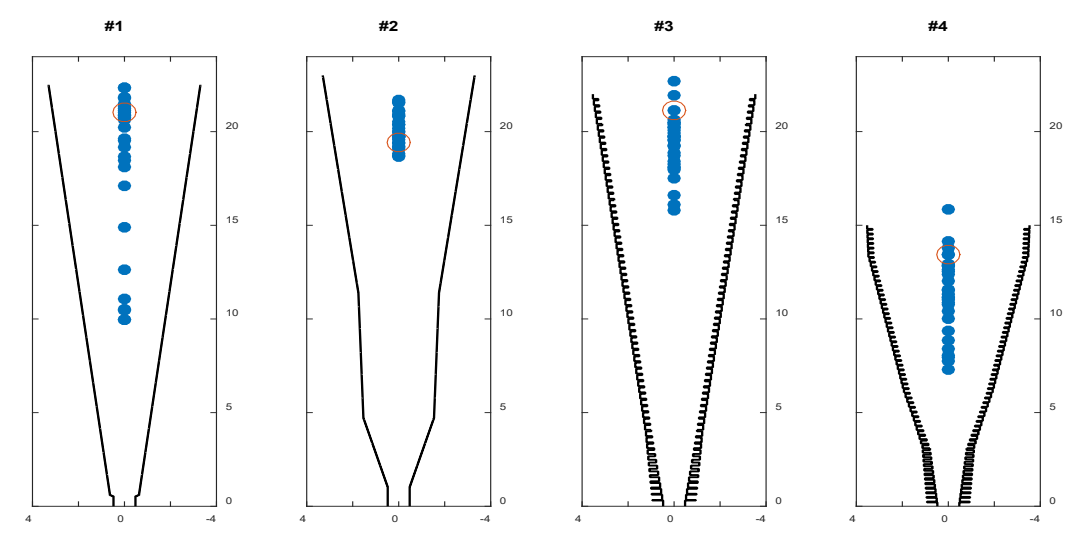

Fig. 2. Optimised profiles of four investigated feed horns. All dimensions are in wavelengths. Dots show phase centre positions at different frequencies (see text).

Normalised frequency dependence of the main performance parameters is shown in Fig. 3. Both corrugated horns have the cross-polarization level better than $20 \mathrm{~dB}$ within $67 \%$ (octave) bandwidth reaching levels of 30-50 dB within fractional bandwidth of $47 \%$. Horn \#1 is the narrowest band as expected with cross-polarization reaching $30 \mathrm{~dB}$ only at $\approx 7 \%$ wideband around centre frequency. Discrete section smooth wall horn antenna \#2 performs similarly to corrugated horns within $14 \%$ of central band with cross-polarization better than $30 \mathrm{~dB}$ and better than $20 \mathrm{~dB}$ within $50 \%$ bandwidth. All horns have similar $13 \mathrm{~dB}$ level beam widths and similar directivities. Input return loss is better than $-30 \mathrm{~dB}$ above normalised frequency of 0.75 for horns \#2 - \#4 and better than -20 dB for horn \#1. Phase centre positions at multiple frequencies are shown in Fig. 2 with filled dots with highlighted points showing position at central frequency. Surprisingly, horn \#2 has the most stable phase centre position. 

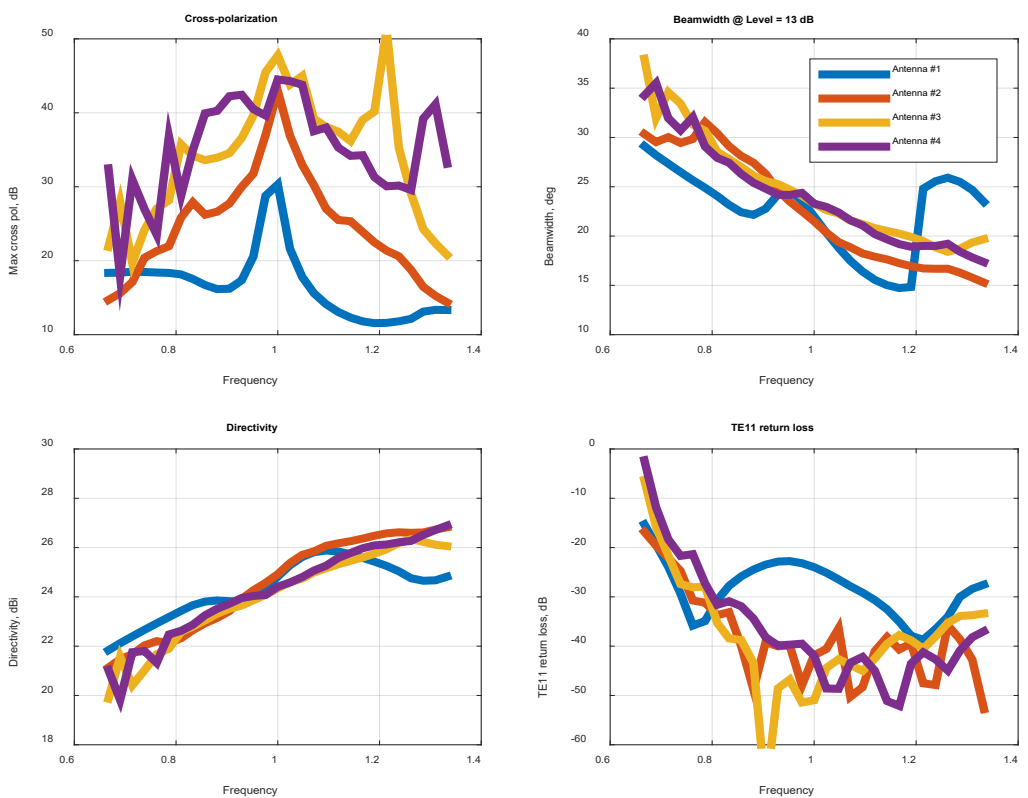

Fig. 3. Maximum cross-polarization level, $13 \mathrm{~dB}$ level beam width, directivity and input return loss of the four proposed profiles vs. relative frequency.

Figure 4 shows comparison of total feed efficiency calculated for subtended angle of $21^{\circ}$, which includes sub-efficiencies of illumination, spill-over, phase, crosspolarization and secondary mirror blockage [7]. Reflector surface and secondary mirror alignment accuracy are not considered in this analysis. All horns reach almost $80 \%$ efficiency near centre frequency with the flattest response in case of corrugated horn \#3 and \#4. Horn \#4 has $\approx 5 \%$ worse maximum efficiency due to its decreased length and accordingly decreased phase efficiency, which may also cause relatively unstable phase centre position evident in Fig. 2. Corrugated horns \#3 and \#4 have efficiency better than $60 \%$ and $55 \%$ within octave bandwidth, and smooth profiled horn \#2 reaches efficiency better than $60 \%$ within bandwidth of $40 \%$.

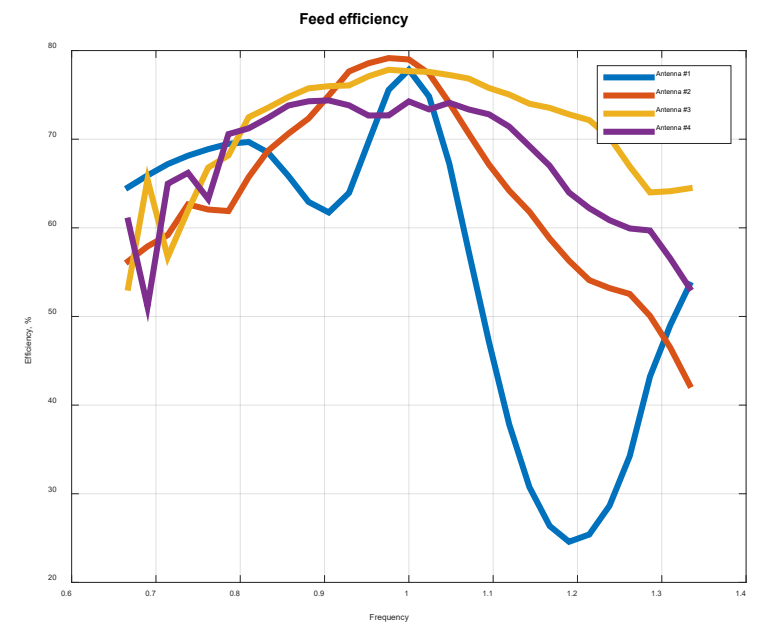

Fig. 4. Total feed efficiency vs. relative frequency in case of RT-32 secondary subtended angle of $21^{\circ}$. 


\section{CONCLUSIONS}

Four horn profiles have been investigated for possible Irbene RT-32 feed antenna design. Smooth wall Potter profile (antenna \#1) is the narrowest band, but at the same time the simplest and most cost-effective option. Good candidate for $\mathrm{L} / \mathrm{S}$ band feed design is profile \#2 due to its relatively low cost and small weight, but efficiency performance is comparable to the corrugated horns. For instance, one could achieve RT-32 feed efficiency better than $50 \%$ with maximum of $79 \%$ within frequencies of 1.2 to $2.32 \mathrm{GHz}$ with a smooth profile horn possibly fabricated from sheet metal with total horn length of $3.67 \mathrm{~m}$ and aperture diameter of $1.1 \mathrm{~m}$. For the absolute widest band performance, full length corrugated horn such as \#3 is the best option and would be a good solution for RT-32 K band feed design. In this case, efficiency of better than $50 \%$ (neglecting the surface accuracy of RT-32) within 18 to $36 \mathrm{GHz}$ could be achieved, with horn length and aperture diameter of $24 \mathrm{~cm}$ and 7.3 $\mathrm{cm}$, respectively. With additional optimisation of horn \#3 profile, it may be possible to increase the efficiency at octave band edges even more. Current design of profile \#4 has $\approx 5 \%$ less efficiency in comparison with full length profiles, which in some situations may be outweighed by $30 \%$ smaller physical size.

Further research will be conducted to improve the horn designs and design software. Nevertheless, the current results allow concluding that the currently implemented design techniques are capable for in-house design of high-performance feed horns for Irbene parabolic antennas.

\section{REFERENCES}

1. Goldsmith, P. F. (1998). Quasioptical systems: Gaussian beam quasioptical propagation and applications. Wiley-IEEE. ISBN: 978-0-7803-3439-7

2. Ruiz-Cruz, J. A., Montejo-Garai, J.R., \& Rebollar, J.M. (2010). Computer Aided Design of Waveguide Devices by Mode-Matching Methods. Passive Microwave Components and Antennas, 117-140. DOI: 10.5772/9403

3. Polo-Lopez, L., Ruiz-Cruz, J.A., Corcoles, J., \& Leal-Sevillano, C.A. (2015). Analysis and Design of Horn Antennas with Arbitrary Profile Using Mode-Matching. In Congress on Numerical Methods in Engineering, CMN 2015, 29 June-2 July 2015, Lisbon, Portugal.

4. Potter, P. D. (1963). A New Horn Antenna with Suppressed Sidelobes and Equal Beam Widths. Microwave J., 6, 71-78.

5. Clarricoats, P. J. B., \& Olver, A. D. (1984). Corrugated horns for microwave antennas. The Institution of Engineering and Technology. ISBN: 9780863410031

6. Zhang, X. (1993). Design of Conical Corrugated Feed Horns for Wide-Band HighFrequency Applications. IEEE Transactions on Microwave Theory and Techniques, 41 (8), 1263-1274. DOI: 10.1109/22.241664

7. Olver, A.D., Clarricoats, P.J., Kishk, A.A., \& Shafai, L. (1994). Microwave horns and feeds. The Institution of Engineering and Technology. ISBN: 9781849193955 
POTENCIĀLU APSTAROTĀJU RISINĀJUMU IZPĒTE PIELIETOJUMAM RT-32 RADIO TELESKOPĀ

\section{Bleiders}

Kopsavilkums

Rakstā tiek salīdzināti dažādi sekundārā fokusa apstarotāju antenu risinājumi, kas optimizēti potenciālam pielietojumam Irbenes RT-32 radio teleskopam. Apskatītās antenas ietver ruporantenas ar gludu virsmu, kā arī skalārās ruporantenas ar lineāriem un optimizētas formas profiliem. Ruporantenu izkliedes parametru un izstaroto lauku parametru simulācijām tiek izmantota modālās salāgošanas metode. Ruporantenu profilu optimizācijai tiek izmantots ǵenētiskais algoritms, optimizāciju veicot maksimāli augsta ortogonālo polarizāciju atdalījuma līmeņa, stara simetrijas un apertūras efektivitātes iegūšanai. Lai arī apskatītie apstarotāji ir izmantojami jebkuram frekvenču diapazonam, dažādi risinājumi l̦auj izvēlēties labāko kompromisu starp elektrisko veiktspēju un mehānisko sarežǵìitību.

Atslēgas vārdi: antenu optimizācija, apstarotāja antena, Irbenes $R T-32$ radio teleskops 